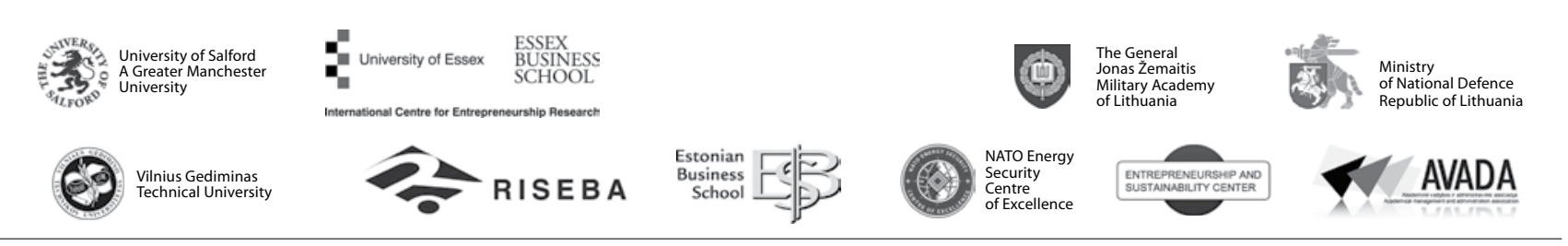

JOURNAL OF SECURITY AND SUSTAINABILITY ISSUES

ISSN 2029-7017 print/ISSN 2029-7025 online

2017 March Volume 6 Number 3

http://dx.doi.org/10.9770/jssi.2017.6.3(2)

\title{
SAFETY MEASUREMENT PECULIARITIES IN SELECTED COUNTRIES
}

\author{
Ladislav Kabát ${ }^{1}$, Stanislav Filip ${ }^{2}$, Lubica Filipováa ${ }^{3}$ \\ ${ }^{1,2}$ School of Economics and Management in Public Administration, Bratislava, \\ Slovak Republic, Furdeková 16, 85104 Bratislava, Slovenská republika \\ ${ }^{3}$ Faculty of Economics and Business, Pan-European University, Tematinska 10, \\ 85105 Bratislava, Slovenská republika
}

E-mails:'ladislav.kabat@vsemvs.sk²stanislav.filip@vsemvs.sk, ${ }^{3}$ lubica.filipova@panerouni.com

Received 20 May 2016; accepted 15 December 2016

\begin{abstract}
The safety and security research is generally presented as a problem of two levels. The first level is focused on individuals and social groups while the second level deals with the safety and security issues on a country level. Research on both levels, however, is very often concentrated on the life or health threat in direct connection with war conflicts, terrorism, organised crime, political or social persecution and natural disasters. Nevertheless, such understanding and evaluation of safety and security does not comply with the present reality. There exist a wide range of scientific studies proving that the present understanding of human safety and security consists of several dimensions which might not be directly linked to actual war activities. The human safety and security of people in a broad sense could be jeopardized also by unfair practices or abuse of political power by governmental bodies, corruption in national economies, discrimination of minorities, drugs and black markets. The threat to the safety and security of individuals and countries is a multidimensional problem and its scope, intensity and dynamics should be measured by adequate tools and should be understood as a standard dimension of the quality of life. A specific tool should be adopted for measuring the safety and security in people's life and for measuring safety and security on a country level. Current statistical and other exact methods enable researchers to perform qualitative and quantitative measurements and evaluate the safety and security in a broad scope and with needed depth and qualification. The aim of this paper is to review present trends in the measurement of the safety and security levels in context with actual impacts of external threats from international war conflicts, terrorist attacks and corruption practices and to underline the activities of countries and the international community to stop, or to reduce such threats. To measure these dimensions of safety and security, some selected indexes and indicators of international standards will be used. Our aim is to demonstrate their application in mapping and evaluating the safety and security situation within the European Union countries and particular attention to the performance of Slovakia.
\end{abstract}

Keywords: safety measurement, quality of life, safety potential, global peace index, personal security index

Reference to this paper should be made as follows: Kabát, L.; Filip, S.; Filipová, L. 2017. Safety measurement peculiarities in selected countries, Journal of Security and Sustainability Issues 6(3): 343-356. http://dx.doi.org/10.9770/jssi.2017.6.3(2)

JEL Classification: H 12, H56, K14, K32

\section{Introduction}

The consequences of natural disasters and especially of disasters caused by human activities were, and still are, a basis for decisions of individuals or even social groups on where to live and to work, where to establish and to run their business, to spend vacations or leisure time. There are various official and unofficial public and private institutions active in this field and aiming to assist with such decisions. Among them, at least the national and international statistical offices, United Nations institutions, World Bank, OECD and Eurostat should be mentioned. These institutions, through their specific channels, provide systematic and reliable information on a broad spectrum of the peoples' life, including the safety and security aspects of territorial units and the other in- 
teresting destinations. The relevant data are published mainly in aggregated figures for specific countries levels.

However, the additional useful information as population density, landscape, climate and water indicators of examined territorial regions or other important factors influencing safety and security perception are often required for deeper analysis of lower administrative and regional structures. After specific mathematical arrangement, this data could create a multidimensional set of various data, which are recorded and studied over a long time span. The application of sophisticated mathematical and statistical methods is the only possible way of analysing such data sets and utilizing their objective value to measure and estimate the safety and security of individuals and social groups living, or visiting such public areas. These methods include the multi criteria regress analysis, factor analysis, cluster and discrimination analysis.

The global, regional and local safety and security measurements should be considered as an integral part of public sector research. The numerous scientific studies on global and regional security confirm that their results provide the public and other competent bodies with the arguments and possibilities to compare, to evaluate the situation in these entities and consequently to adopt the adequate important decisions to safeguard the areas requiring special security measures.

At the present time, the scientific research deals with various aspects of public safety and security issues as well as with evaluation of the security of countries and regional levels. Up to now, however, there is no single, generally adopted definition of the safety and security level. In various publications, it is rather described through the broad spectrum of indicators related to the safety and security field. (e. g. Rezk et al. 2015; Travkina 2015; Teivāns-Treinovskis, Amosova 2016; Tvaronavičienė 2016; Štitilis et al. 2016; Gasparènienè et al. 2016; Barberis et al. 2017; Gandini et al. 2017; Oates et al. 2017).

According ( Buzan et col. 2005) the safety and security is understood as a complex system which includes the military, political, economics, societal and environmental subsystems. (Wiberg,1996) points at the necessity of evaluating the security through the comparative approach, it means in relationship with or against some other subjects. (Drennan. and Mc Connell, 2007) examine the impact of security on the broad aspects of the publicsector activities. (Antušák, 2005) understands the safety and security situation and its measures as basic indices of the quality of life of individuals, social groups, countries or regions. Similar positions could be identified in scientific papers, presented by authors studying systematically the impact of safety and security threats on the behaviour of individual, social groups or state, namely (Rektořík 2004, Horák, 2015, Šimák, 2016, Novák, 2010 and, Míka, 2013, Víghová et.al 2017) should be presented.

One of the first attempts to measure the safety and security of citizens has been published in 1998 by Centre for International Statistics at the Canadian Council on Social Development. This Centre in cooperation with the Insurance Bureau of Canada developed a model for estimating the "Personal Security Index"(1998). The Personal Security Index (PSI) comprises economic, physical and healthy security indices as a combination of subjective and objective indicators. The PSI has, since the Stiglitz-Sen-Fittousi Report (2010), been significantly restructuralised and expanded in the number of its components. Its last version known as the Human Security Index (HIS) (Hastings, 2010) is composed of 30 indicators, which are grouped into three pillars relevant to the safety of population and countries, namely those related to - economic, environment and social aspects of life. The safety aspects are directly represented by environmental vulnerability, political terror, poverty, healthy life expectancy, access to quality water, political stability and control of corruption measures. The last report on HSI covers over 230 countries and political entities and by content and methodology is relatively close to the Human Development Index of the UNDP (2015).

The different approach to citizens' security measurement was presented by the research society Red de Seguridad Defense de América Latina in 2013. Under their study, the evaluation of crime, traffic accident mortalities, domestic violence, expenses on security and police distribution in selected countries generally and particularly in their regions are presented as the Public Security in Central America: Costa Rica, El Salvador, Guatemala, Honduras, Nicaragua and Panama (Resedal 2013). The interesting results on measurement and 
evaluation of global physical and economic security are published by the (international non-profit think tank) Institute for Economics and Peace in Global Terrorism Index (2015). The research of this international think tank is based on data from the Global Terrorism Database collected and processed under the auspices of the National Consortium for Study of Terrorism and Responses to Terrorism (START) and the University of Maryland. Currently, the database has processed more than 150000 terrorist incidents. The Global Terrorism Index (GTI) measures the impact of global terrorist attacks on a particular country. Currently the most targeted country is Afghanistan.

Another large-scale research project is executed by the Institute for Economics and Peace (http://economicsandpeace.org/. It is concentrated on measuring peace at the global and national level, which allows researchers to assess the social, political and economic factors that create peace. Annually the Global Peace Index (GPI) is published, (2015) for more than 160 countries. The GPI is derived from the 22 selected partial indices, relevant for safety and security of individuals, social groups and countries.

This index ranks countries according to their levels of "peacefulness", or ability to stabilize the peace in their countries and to absorb the unexpected disturbances caused by internal or external attacks. Also, the series of national indicators have been developed to explore in detail the subnational level of peace factors.

The development in the field of safety and security is systematically mapped and presented as the „Positive Peace Report "(2015). Specific detailed analysis of selected factors, which are significant for stabilization of peace is published as „Peace and Corruption “(2015. The study shows how the pillars of the Global Peace Index deteriorate with growing corruption. The most influenced consequences are growing political terror, political instability, violent crime rate, violent demonstrations, organized conflict, trafficking and smuggling of small arms and light weapons, homicide rate and the level of perceived criminality in society. This conclusion coincides with the Corruption Perception Report by Transparency International (2015). Very sensitive original data on corruption indices are collected and validated with 12 different data sources from 11 different recognized institutions.

The Corruption Perception Index assesses individual countries according to the level of public perception toward the corruption in their societies. The majority of EU countries belong to the leaders in this ranking. The position of Slovakia deserves more attention because of the last negative grading by OECD and World Economic Forum (http://uk.businessinsider.com/wef-corruption-index-the-most-corrupt-countries-in-the-oecd-2016-9. Slovakia was classified as the second most corrupt country among the developed countries. In our paper we demonstrate also the negative impacts of corruption to the national economies.

Research Institute of the Credit Suisse presented a comprehensive study „Global Wealth Data book 2015“, where the wealth, namely its distribution, is percepted as a part of economic (in)security of individuals, regions and even a country. The data indicate extremely high inequalities in wealth allocation within households, as well as among the various countries and regions. All these findings are classified as the jeopardy of the peaceful status. Similar conclusion could be derived from the „Prosperity index “(2015) published by worldwide known Legatum Institute (http://www.li.com).

Systematic access to sufficient quality food became over time one of the sensitive factors in evaluating the personal safety and security situation of households, regions and countries. Particularly, the high proportion of people in developing countries is still fighting with very basic problems in obtaining vitally needed food. To underline this situation, the Economist Intelligence Unit produces an annual report on food security in individual countries all over the world. Its Global Food Security Report (http://foodsecurityindex.eiu.com/) presents not only the aggregated results and evaluation of individual countries by the Global Food Security Index (GFSI) but also detailed information on the current food situation in individual countries. Namely, the affordability, availability, quality and safety of food is specified in more detailed indicators. Some important economic parameters and household income characteristics are included as well (Guide, 2015). 
Since 2013 the Eurostat also provides complex information on security measurements as a part of the quality of life studies. Based on the requirements of the European Council it has prepared a methodology to measure, to compare and to illustrate eight pillars of quality of life in EU countries. Among them personal safety is also included. The results are published annually in „Quality of life. Facts and views “[18]. These results could be used for comparative studies with the above presented evaluations.

The Ministry of Interior Affairs of Slovak Republic deals also systematically with the special security issues, its measurements and evaluation. Some statistical data reflecting the national and regional findings on crime, traffic accidents, fires and extraordinary events are presented via websites of the Police Corps (http://www. minv.sk/?statistiky-dokumenty). The annually published Maps of crimes in the Slovak Republic present the structure and number of crimes in individual police districts of Slovakia (2015).

The main objective of this paper is to present and to evaluate the newest information on the measurement the safety and security issue in the frame of the European Union countries, with particular attention to the results and position of Slovakia.

\section{Data and Methods}

Considering the lack of specific terminology for describing the safety and security situation and its levels, we need to define some new terms and categories related to the global and regional citizens' security in accordance with the terminology used in foreign scientific and professional literature. A core target of our further presentation will be the estimation of the countries' security potential. This phenomenon is about specific place, region, country, as well as with individuals, social groups and cities. We propose to express this security potential as a composite indicator based on indices reflecting the most relevant information on the safety and security status of citizens, social groups, cities, regions and countries.

Namely, the indices reflecting economic status of individual countries, their ability to protect peace and to fight with terrorism, the ability to fight with corruption in their societies, the ability to protect the individual citizens, or human security and the composite index of national capability will be used for deriving the composite security potential indicator (CSPI):

- GDP per capita in PPS

- Global Peace Index

- Global Food Security Index

- Corruption Perception Index

- Human Security Index

- Global Terrorism Index

- Composite Index of National Capability

The adopted indices represent their latest published values (2014-2016). For deriving the statistically significant indices, where needed, the factor analysis, cluster and discrimination analysis has been used. Before such analysis, however, all the variables have been normalized by the min-max transformation. This means the original values of these variables were projected to $(0,1)$ interval. To solve this problem, we adopted the following rescaling transformation rule for recalculating the original data $\mathrm{Xi}$ to new values $\mathrm{Xi}$-Trans:

$$
\mathbf{X i}-\operatorname{Trans}=(\mathbf{X i}-\operatorname{Min}\{\mathbf{X i}\}) /(\operatorname{Max}\{X i\}-\operatorname{Min}\{X i\})
$$

for variables that measure the positive contribution to safety and security potential (GDP per capita, Global Peace Index, ...) and

$$
\operatorname{Xi}-\operatorname{Trans}=(\mathbf{X i}-\operatorname{Max}\{\mathbf{X i}\}) /(\operatorname{Min}\{X i\}-\operatorname{Max}\{X i\})
$$

for variables that measure the negative contribution to safety and security potential (Corruption, Terrorism, ...). The above transformation made easier interpretation of the final results of calculation possible. 
Also, the multiple linear regression (Koop, 2013) will be applied for further data processing. The main goal is to derive the statistical model for estimation of the security potential of regions, cities and municipalities based on generally accessible information. Information sources of the World Bank, Eurostat, OECD, FAO and other recognised international institutions involved in the safety and security policy will also be utilized.

The derived results will be presented in easily readable tables and indexes. They will serve the citizens and institutions of public administration for evaluating the quality of safety aspects of peoples' life in selected geographical and administrative units, special places and the other regional units.

Special attention is devoted to the application of the Composite Index of National Capabilities (CING). This measure was derived by Singer (2009) for the estimation of the countries' total safety and security potential. The value of CING for a particular country is calculated according to the formula

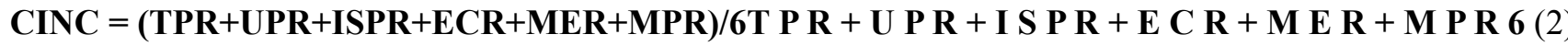

Where

TPR = population of country - ratio to world,

$\mathrm{UPR}=$ urban population of country - ratio to world,

ISPR $=$ iron and steel production of country - ratio to world,

$\mathrm{ECR}=$ primary energy consumption - ratio to world,

MER = military expenditure - ratio to world,

MPR $=$ military personnel - ratio to world.

The CINC could be considered as the super-indicator of the national capability to protect its sovereignty and to participate in the international fight for peace. Taking into consideration the scope of this paper we present the most important results and methods of safety and security evaluation on country levels. Only seven, most popular indexes will be used for deriving the super- indicator reflecting the total safety and security potential for individual countries.

\section{Results and discussion}

Based on the available statistical data and research results, we start with the presentation of the safety and security indexes of individual EU member countries. Two countries - Luxemburg and Malta are not presented because of the absence of some core data. The values of all selected indices are presented in Table 1 . The last two rows represent the minimal and maximal values of the individual indices.

Concerning the individual country, its complex performance under the presented set of criteria (indexes) and the presented data is problematic. The values of individual indices are represented by data of different nature and different size. For example, in the case of Slovakia, its economic performance could be compared only with the economic performance of other EU countries. Similarly, the corruption perception of Slovakia could by compared only with another country and the same index. The aggregated comparison among the EU countries, embracing the all seven indexes is, at this stage, not possible. To do it, the transformation of data according the formulas (1a) and (1b) was needed, Table 2. 
Table 1. Values of selected and security indices for EU countries

\begin{tabular}{|c|c|c|c|c|c|c|c|c|}
\hline \multirow[t]{2}{*}{ Country } & \multirow[t]{2}{*}{ Code } & $\begin{array}{c}\text { GDP } \\
\text { per capita } \\
\text { in euro } \\
\end{array}$ & $\begin{array}{l}\text { Global } \\
\text { Peace } \\
\text { Index }\end{array}$ & $\begin{array}{c}\text { Global Food } \\
\text { Security } \\
\text { Index } \\
\end{array}$ & $\begin{array}{c}\text { Corruption } \\
\text { Perception } \\
\text { Index } \\
\end{array}$ & $\begin{array}{l}\text { Human } \\
\text { Security } \\
\text { Index }\end{array}$ & $\begin{array}{c}\text { Global } \\
\text { Terorism } \\
\text { Index } \\
\end{array}$ & $\begin{array}{c}\text { Composite } \\
\text { Index of National } \\
\text { Capability } \\
\end{array}$ \\
\hline & & GDP pc & GPI & GFSI & CPI & HSI & GTI & CINC \\
\hline Austria & AUT & 36400 & 1,278 & 85,100 & 76 & 0,755 & 2,088 & 0,003 \\
\hline Belgium & BEL & 33700 & 1,528 & 79,500 & 77 & 0,716 & 1,977 & 0,004 \\
\hline Denmark & DNK & 35500 & 1,246 & 82,600 & 91 & 0,781 & 0,091 & 0,001 \\
\hline Finland & FIN & 31000 & 1,429 & 79,900 & 90 & 0,801 & 0,000 & 0,002 \\
\hline France & FRA & 30400 & 1,829 & 83,800 & 70 & 0,732 & 4,553 & 0,019 \\
\hline Germany & $\mathrm{DEU}$ & 35900 & 1,486 & 83,900 & 81 & 0,753 & 3,442 & 0,024 \\
\hline Greece & GRC & 20300 & 2,044 & 73,500 & 46 & 0,668 & 4,976 & 0,004 \\
\hline Ireland & IRL & 41600 & 1,433 & 85,400 & 75 & 0,702 & 3,663 & 0,001 \\
\hline Italy & ITA & 27400 & 1,774 & 77,000 & 44 & 0,701 & 3,364 & 0,017 \\
\hline Netherlands & NLD & 36900 & 1,541 & 85,00 & 81 & 0,735 & 0,429 & 0,006 \\
\hline Portugal & PRT & 22300 & 1,356 & 80,500 & 63 & 0,707 & 0,267 & 0,002 \\
\hline Spain & ESP & 26300 & 1,604 & 78,900 & 58 & 0,700 & 2,622 & 0,011 \\
\hline Sweden & SWE & 35400 & 1,461 & 82,900 & 89 & 0,821 & 3,083 & 0,003 \\
\hline UK & UK & 31500 & 1,830 & 81,600 & 81 & 0,703 & 5,613 & 0,021 \\
\hline Bulgaria & BGR & 13300 & 1,646 & 61,00 & 41 & 0,701 & 2,421 & 0,001 \\
\hline Croatia & HRV & 16700 & 1,633 & 67,730 & 51 & 0,725 & 0,115 & 0,001 \\
\hline Cyprus & CYP & 23300 & 1,994 & 74,780 & 61 & 0,675 & 3,080 & 0,000 \\
\hline Czech Rep & $\mathrm{CZE}$ & 24500 & 1,360 & 74,900 & 56 & 0,754 & 2,484 & 0,002 \\
\hline Estonia & EST & 21400 & 1,732 & 72,979 & 70 & 0,725 & 0,076 & 0,000 \\
\hline Hungary & HUN & 19500 & 1,534 & 71,400 & 51 & 0,727 & 1,187 & 0,002 \\
\hline Latvia & LVA & 18500 & 1,680 & 69,897 & 55 & 0,735 & 0,000 & 0,000 \\
\hline Lithuania & LTU & 21100 & 1,735 & 72,680 & 61 & 0,726 & 0,000 & 0,000 \\
\hline Poland & POL & 19700 & 1,557 & 74,200 & 62 & 0,715 & 0,000 & 0,007 \\
\hline Romania & ROM & 16300 & 1,649 & 63,300 & 46 & 0,707 & 0,000 & 0,003 \\
\hline Slovakia & SVK & 22000 & 1,603 & 70,700 & 51 & 0,774 & 0,000 & 0,001 \\
\hline Slovenia & SVN & 23700 & 1,408 & 75,140 & 60 & 0,729 & 0,000 & 0,000 \\
\hline & MIN & 13300 & 1,246 & 61,000 & 41 & 0,668 & 0,000 & 0,000 \\
\hline & MAX & 41600 & 2,044 & 85,400 & 91 & $\mathbf{0 , 8 2 1}$ & 5,613 & 0,024 \\
\hline
\end{tabular}

Source: Global Peace Index, calculation authors

Table 2. Values of selected safety and security indices for EU countries - Recalculated

\begin{tabular}{|l|c|c|c|c|c|c|c|c|}
\hline \multirow{2}{*}{ Country } & \multirow{2}{*}{ Values of selected safety and security indices for EU countries - Recalculated } \\
\hline & \multirow{2}{*}{ Code } & $\begin{array}{c}\text { GDP } \\
\text { per capita } \\
\text { in euro }\end{array}$ & $\begin{array}{c}\text { Global } \\
\text { Peace } \\
\text { Index }\end{array}$ & $\begin{array}{c}\text { Global Food } \\
\text { Security } \\
\text { Index }\end{array}$ & $\begin{array}{c}\text { Corruption } \\
\text { Perception } \\
\text { Index }\end{array}$ & $\begin{array}{c}\text { Human } \\
\text { Security } \\
\text { Index }\end{array}$ & $\begin{array}{c}\text { Global } \\
\text { Terorism } \\
\text { Index }\end{array}$ & $\begin{array}{c}\text { Composite } \\
\text { Index of National } \\
\text { Capability }\end{array}$ \\
\cline { 2 - 10 } & GDP pc & GPI & GFSI & CPI & HSI & GTI & CINC \\
\hline Austria & AUT & 0,816 & 0,960 & 0,988 & 0,700 & 0,570 & 0,628 & 0,099 \\
\hline Belgium & BEL & 0,721 & 0,647 & 0,758 & 0,720 & 0,312 & 0,648 & 0,155 \\
\hline Denmark & DNK & 0,784 & 1,000 & 0,885 & 1,000 & 0,734 & 0,984 & 0,054 \\
\hline Finland & FIN & 0,625 & 0,771 & 0,775 & 0,980 & 0,867 & 1,000 & 0,081 \\
\hline France & FRA & 0,604 & 0,269 & 0,934 & 0,580 & 0,414 & 0,189 & 0,784 \\
\hline Germany & DEU & 0,799 & 0,699 & 0,939 & 0,800 & 0,552 & 0,387 & 1,000 \\
\hline Greece & GRC & 0,247 & 0,000 & 0,512 & 0,100 & 0,000 & 0,113 & 0,151 \\
\hline Ireland & IRL & 1,000 & 0,766 & 1,000 & 0,680 & 0,217 & 0,347 & 0,018 \\
\hline Italy & ITA & 0,498 & 0,338 & 0,656 & 0,060 & 0,214 & 0,401 & 0,721 \\
\hline Netherlands & NLD & 0,834 & 0,630 & 0,984 & 0,800 & 0,438 & 0,924 & 0,228 \\
\hline Portugal & PRT & 0,318 & 0,862 & 0,799 & 0,440 & 0,251 & 0,952 & 0,069 \\
\hline Spain & ESP & 0,459 & 0,551 & 0,734 & 0,340 & 0,208 & 0,533 & 0,468 \\
\hline Sweden & SWE & 0,781 & 0,731 & 0,898 & 0,960 & 1,000 & 0,451 & 0,116 \\
\hline UK & UK & 0,643 & 0,268 & 0,844 & 0,800 & 0,229 & 0,000 & 0,878 \\
\hline
\end{tabular}




\begin{tabular}{|l|c|c|c|c|c|c|c|c|}
\hline Bulgaria & BGR & 0,000 & 0,499 & 0,000 & 0,000 & 0,217 & 0,569 & 0,051 \\
\hline Croatia & HRV & 0,120 & 0,515 & 0,276 & 0,200 & 0,370 & 0,980 & 0,016 \\
\hline Cyprus & CYP & 0,353 & 0,063 & 0,565 & 0,400 & 0,041 & 0,451 & 0,000 \\
\hline Czech Rep & CZE & 0,396 & 0,857 & 0,570 & 0,300 & 0,562 & 0,557 & 0,090 \\
\hline Estonia & EST & 0,286 & 0,391 & 0,491 & 0,580 & 0,369 & 0,986 & 0,002 \\
\hline Hungary & HUN & 0,219 & 0,639 & 0,426 & 0,200 & 0,385 & 0,789 & 0,059 \\
\hline Latvia & LVA & 0,184 & 0,456 & 0,365 & 0,280 & 0,439 & 1,000 & 0,006 \\
\hline Lithuania & LTU & 0,276 & 0,387 & 0,479 & 0,400 & 0,375 & 1,000 & 0,010 \\
\hline Poland & POL & 0,226 & 0,610 & 0,541 & 0,420 & 0,308 & 1,000 & 0,282 \\
\hline Romania & ROM & 0,106 & 0,495 & 0,094 & 0,100 & 0,250 & 1,000 & 0,126 \\
\hline Slovakia & SVK & 0,307 & 0,553 & 0,398 & 0,200 & 0,497 & 1,000 & 0,052 \\
\hline Slovenia & SVN & 0,367 & 0,797 & 0,580 & 0,380 & 0,396 & 1,000 & 0,006 \\
\hline
\end{tabular}

Source: Global Peace Index, calculation authors

These transformation steps make easier interpretation of the new data. Their values are non-negative and less or equal to 1 . All factors with these new recalculated data could be interpreted as factors with a "positive" impact on safety and security level, where higher value indicates higher positive impact on safety and security level.

Having in mind this transformation outcome, the above data could be interpreted partially for individual indices and individual countries. For example, the economic performance of Slovakia according the new measure is defined by coefficient 0,307 , while the economic performance of Romania is defined by coefficient 0,106 . Analogically, Slovakia's total or aggregated performance under the whole set of criteria could be formulated by sum:

$$
(0,307+0,553+, 0,398+0,200+0,497+1+0,052)=3,006 .
$$

The same value of aggregated performance for Romania would be 2,171, which indicates better performance of Slovakia.

In Table 3 we present a slightly different approach in estimating the aggregated safety and security performance, or the composite security potential indicator. The partial data shows the following ranking position of the individual country among all EU countries under the specific indices (criteria).

Table 3. Ranking of selected safety and security indices for EU countries

\begin{tabular}{|c|c|c|c|c|c|c|c|c|c|c|}
\hline \multicolumn{11}{|c|}{ Ranking of selected safety and security indices for $\mathrm{EU}$ countries } \\
\hline \multirow[t]{2}{*}{ Country } & \multirow[t]{2}{*}{ Code } & 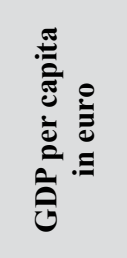 & 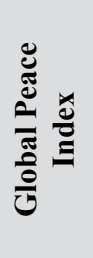 & 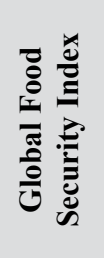 & 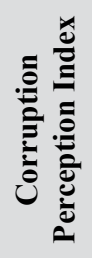 & 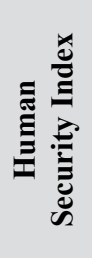 & 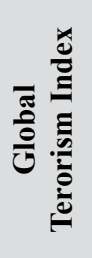 & 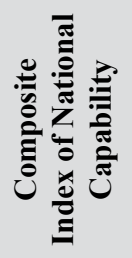 & $\begin{array}{c}\text { SUM } \\
\text { RANKS }\end{array}$ & $\begin{array}{c}\text { RANK } \\
\text { TOTAL }\end{array}$ \\
\hline & & GDP pc & GPI & GFSI & CPI & HSI & GTI & CINC & & \\
\hline Austria & AUT & 3 & 2 & 2 & 8 & 4 & 15 & 12 & 46 & 3 \\
\hline Belgium & BEL & 7 & 10 & 11 & 7 & 16 & 14 & 8 & 73 & 7 \\
\hline Denmark & DNK & 5 & 1 & 7 & 1 & 3 & 9 & 17 & 43 & 1 \\
\hline Finland & FIN & 9 & 6 & 10 & 2 & 2 & 1 & 14 & 44 & 2 \\
\hline France & FRA & 10 & 23 & 5 & 10 & 10 & 24 & 3 & 85 & 11 \\
\hline Germany & DEU & 4 & 9 & 4 & 4 & 6 & 22 & 1 & 50 & 5 \\
\hline Greece & GRC & 20 & 26 & 18 & 23 & 26 & 25 & 9 & 147 & 25 \\
\hline Ireland & IRL & 1 & 7 & 1 & 9 & 21 & 23 & 20 & 82 & 8 \\
\hline Italy & ITA & 11 & 22 & 13 & 25 & 23 & 21 & 4 & 119 & 21 \\
\hline Netherlands & NLD & 2 & 12 & 3 & 4 & 9 & 12 & 7 & 49 & 4 \\
\hline Portugal & PRT & 16 & 3 & 9 & 12 & 18 & 11 & 15 & 84 & 9 \\
\hline
\end{tabular}




\begin{tabular}{|l|c|c|c|c|c|c|c|c|c|c|}
\hline Spain & ESP & 12 & 15 & 12 & 17 & 24 & 18 & 5 & 103 & $\mathbf{1 6}$ \\
\hline Sweden & SWE & 6 & 8 & 6 & 3 & 1 & 20 & 11 & 55 & $\mathbf{6}$ \\
\hline UK & UK & 8 & 24 & 8 & 4 & 20 & 26 & 2 & 92 & $\mathbf{1 4}$ \\
\hline Bulgaria & BGR & 26 & 17 & 26 & 26 & 22 & 16 & 19 & 152 & $\mathbf{2 6}$ \\
\hline Croatia & HRV & 24 & 16 & 24 & 20 & 14 & 10 & 21 & 129 & $\mathbf{2 3}$ \\
\hline Cyprus & CYP & 15 & 25 & 16 & 14 & 25 & 19 & 26 & 140 & $\mathbf{2 4}$ \\
\hline Czech Rep & CZE & 13 & 4 & 15 & 18 & 5 & 17 & 13 & 85 & $\mathbf{1 1}$ \\
\hline Estonia & EST & 18 & 20 & 19 & 10 & 15 & 8 & 25 & 115 & $\mathbf{1 8}$ \\
\hline Hungary & HUN & 22 & 11 & 21 & 20 & 12 & 13 & 16 & 115 & $\mathbf{1 8}$ \\
\hline Latvia & LVA & 23 & 19 & 23 & 19 & 8 & 1 & 24 & 117 & $\mathbf{2 0}$ \\
\hline Lithuania & LTU & 19 & 21 & 20 & 14 & 13 & 1 & 22 & 110 & $\mathbf{1 7}$ \\
\hline Poland & POL & 21 & 13 & 17 & 13 & 17 & 1 & 6 & 88 & $\mathbf{1 3}$ \\
\hline Romania & ROM & 25 & 18 & 25 & 23 & 19 & 1 & 10 & 121 & $\mathbf{2 2}$ \\
\hline Slovakia & SVK & 17 & 14 & 22 & 20 & 7 & 1 & 18 & 99 & $\mathbf{1 5}$ \\
\hline Slovenia & SVN & 14 & 5 & 14 & 16 & 11 & 1 & 23 & 84 & $\mathbf{9}$ \\
\hline
\end{tabular}

Source: Global Peace Index, calculation authors

By summing all the positions for individual countries, we obtain the total aggregated estimation of the performance of that country. The interpretation of individual data, based on Table 3, related to countries and indexes is as follows:

Austria- $3^{\text {rd }}$ position according GDP pc, $\mathbf{2}^{\text {nd }}$ according GPI, $\mathbf{1 2}^{\text {th }}$ according CINC

Sum of ranking values for Austria is 46 , or $3^{\text {rd }}$ position in aggregate evaluation

Slovakia-17 ${ }^{\text {th }}$ by GDP pc, $\mathbf{1 4}^{\text {th }}$ by GPI, $\mathbf{1 8}^{\text {th }}$ according CINC, which places Slovakia in the aggregated $\mathbf{1 5}^{\text {th }}$ position.

The best performing country according all aggregated criteria is Denmark, followed with Finland, Austria, Netherlands and Germany. Among the new member countries, the best performers are - Slovenia and Czech Republic.

\section{More detailed information on individual indices}

For easier understanding of the above presented results, we introduce some additional information on individual indices and their partial elements.

The Global Peace Index incorporates a wide diapason of information on the quality of citizens' life including security indicators. Out of $\mathbf{9 0 0}$ monitored indicators only 22 of them have been selected by experts for further processing. They are:

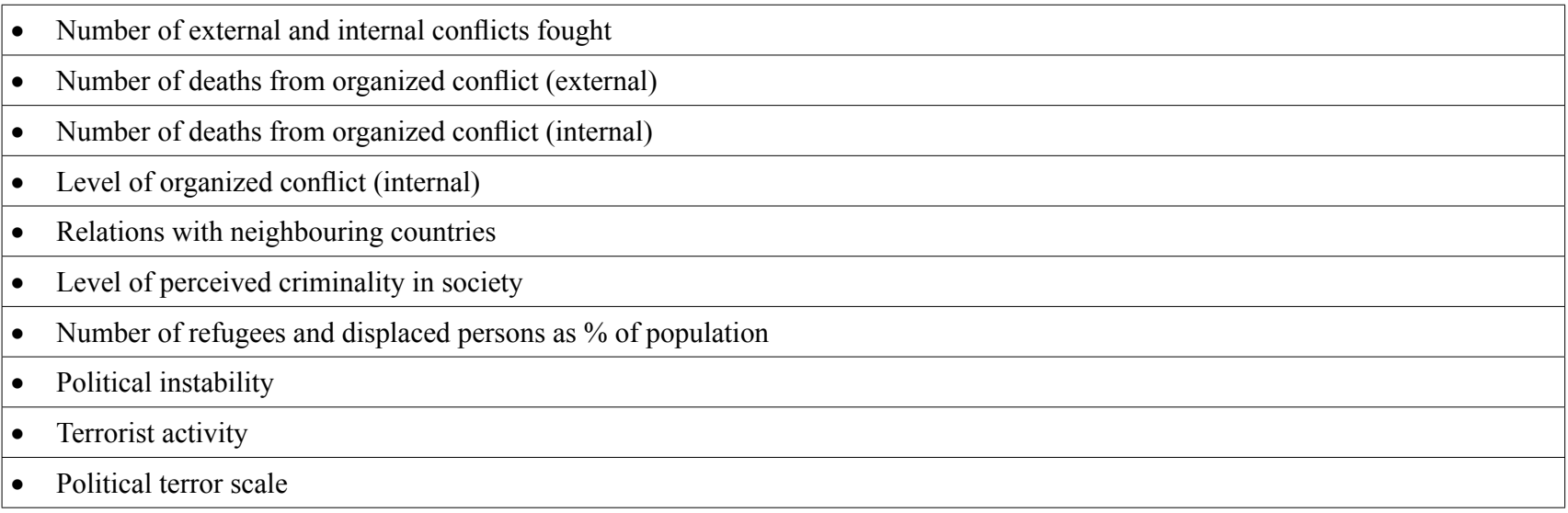


- Number of homicides per 100000 inhabitants

- Level of violent crime

- Likelihood of violent demonstrations

- Number of jailed persons per 100000 inhabitants

- Number of internal security officers and police per 100000 inhabitants

- Military expenditure as a \% of GDP

- Number of armed-services personnel

- Imports of conventional weapons per 100000 inhabitants

- Export of transfers of conventional weapons per 100000 inhabitants

- Financial contribution to UN peacekeeping missions

- Nuclear and heavy weapons capability

- Ease of access to small arms and light weapons

The particular data for these indicators are of quantitative, or qualitative nature. In some cases, they are represented by exact numeric values (number of conflicts, ...), in some cases they are estimated on a specific scale (e.g. 1, ...5). Before calculation of the GPI it is important always to define the positively and negatively contributing individual indicators. The adequate rescaling of initial data could significantly simplify the user's effort to adopt and to apply the derived statistical results.

The Global Peace Index carries not only the safety and security information. It also has the important cognitive functions in studying the relationship among the economic and social environment of the individual countries. As documented in Figure 1, the GPI ranking is statistically significantly related to the GDP pc ranking. This statement is proven by the $\mathrm{R}^{2}$ value 0.4071 and is reliable at the $95 \%$ level. Based on the obtained results of regression analysis it becomes evident that strengthening the level of "peacefulness" of a country leads to its better economic performance and increasing of the GDP values.

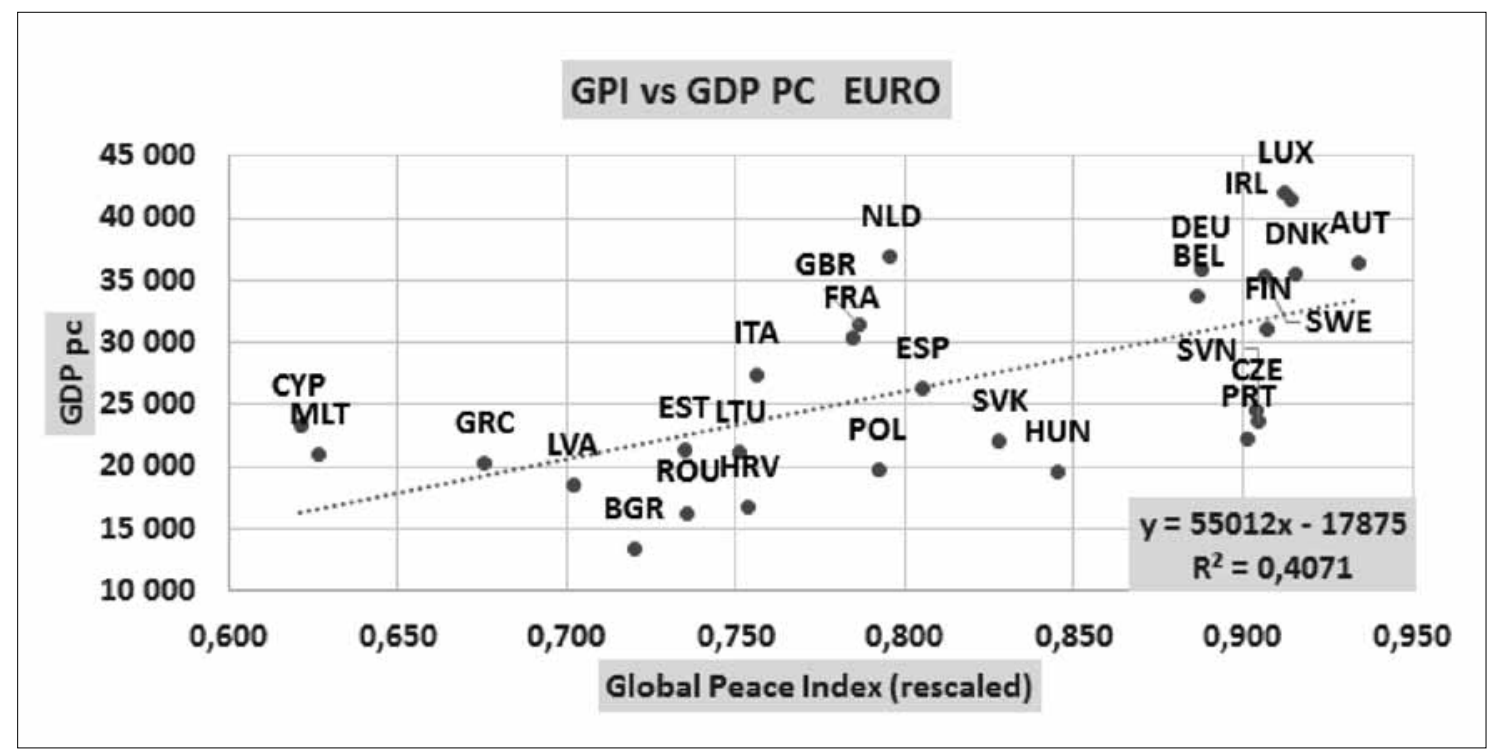

Source: Global Peace Index, calculation authors

Figure 1. Global Peace Index

The more detailed analysis of particular components of GPI shows that higher spending for military, as a part of aforementioned indicators, brings a better (safer) position of countries in the international ranking system and has also the positive impact on economic growth of the country, namely the higher GDP and GDP pc.

The values of the Composite Index of National Capabilities (CING) reflect the broadly defined military power of individual countries calculated according the formula (2). Table 4 demonstrates the assessment of 
EU countries as well as some selected countries. Index CING expresses the share of a particular country in the total world military power. In the case of European Union, it means - Germany's potential represents 2,41 \% of total world power, while Slovakia's share is only $0,14 \%$. Concerning the other countries, the highest potential represents China with almost $20 \%$ of the total military potential.

Table 4. Composite Index of National Capabilities - CING

\begin{tabular}{|c|c|c|c|c|c|c|c|}
\hline \multicolumn{8}{|c|}{ Composite Index of National Capabilities - CING } \\
\hline $\begin{array}{l}\text { Ranking } \\
\text { WORLD }\end{array}$ & Country & CINC & Cumulative CING & $\begin{array}{l}\text { Ranking } \\
\text { WORLD }\end{array}$ & Country & CINC & $\begin{array}{c}\text { Cumulative } \\
\text { CING }\end{array}$ \\
\hline 7 & Germany & 0,0241 & 0,02408 & 1 & China & 0,1986 & 0,19858 \\
\hline 9 & UK & 0,0212 & 0,04524 & 2 & USA & 0,1421 & 0,34073 \\
\hline 10 & France & 0,0189 & 0,06416 & 3 & India & 0,0734 & 0,41417 \\
\hline 11 & Italy & 0,0174 & 0,08158 & 4 & Japan & 0,0427 & 0,45685 \\
\hline 19 & Spain & 0,0114 & 0,09297 & 5 & Russia & 0,0393 & 0,49612 \\
\hline 34 & Netherlands & 0,0056 & 0,09862 & 6 & Brazil & 0,0246 & 0,52072 \\
\hline 43 & Belgium & 0,0039 & 0,10251 & 8 & South Korea & 0,0239 & 0,54460 \\
\hline 45 & Greece & 0,0038 & 0,10633 & 12 & Turkey & 0,0143 & 0,55891 \\
\hline 54 & Sweden & 0,0030 & 0,10931 & 13 & Pakistan & 0,0138 & 0,57268 \\
\hline 5 & Austria & 0,0026 & 0,11188 & 14 & Indonesia & 0,0137 & 0,58639 \\
\hline 61 & Finland & 0,0021 & 0,11402 & 15 & Iran & 0,0135 & 0,59984 \\
\hline 64 & Portugal & 0,0018 & 0,11586 & 16 & North Korea & 0,0129 & 0,61277 \\
\hline 72 & Denmark & 0,0015 & 0,11736 & 17 & Mexico & 0,0123 & 0,62504 \\
\hline 102 & Ireland & 0,0006 & 0,11799 & 18 & Ukraine & 0,0118 & 0,63687 \\
\hline 121 & Luxembourg & 0,0004 & 0,11842 & 20 & Saudi Arabia & 0,0109 & 064775 \\
\hline 29 & Poland & 0,0069 & 0,12536 & 21 & Canada & 0,0107 & 0,65844 \\
\hline 49 & Romania & 0,0032 & 0,12857 & 22 & Egypt & 0,0097 & 0,66815 \\
\hline 58 & Czech Rep & 0,0024 & 0,13092 & 23 & Bangladesh & 0,0081 & 0,67621 \\
\hline 68 & Hungary & 0,0016 & 0,13253 & 24 & Taiwan & 0,0080 & 0,68422 \\
\hline 75 & Slovakia & 0,0014 & 0,13397 & 25 & Thailand & 0,0080 & 0,69219 \\
\hline 76 & Bulgaria & 0,0014 & 0,13539 & 26 & Nigeria & 0,0078 & 0,69999 \\
\hline 105 & Croatia & 0,0006 & 0,13597 & 27 & Vietnam & 0,0076 & 0,70760 \\
\hline 120 & Lithuania & 0,0004 & 0,13641 & 28 & Australia & 0,0071 & 0,71471 \\
\hline 131 & Slovenia & 0,0003 & 0,13676 & 30 & Myanmar & 0,0064 & 0,72111 \\
\hline 133 & Latvia & 0,0003 & 0,13710 & 31 & South Africa & 0,0063 & 0,72742 \\
\hline 138 & Estonia & 0,0003 & 0,13755 & 32 & Colombia & 0,0062 & 0,73360 \\
\hline 144 & Cyprus & 0,0002 & 0,13756 & 33 & Philippines & 0,0057 & 0,73932 \\
\hline \multirow[t]{2}{*}{166} & Malta & 0,0000 & 0,13759 & 35 & Algeria & 0,0053 & 0,74461 \\
\hline & EU CING & 0,13759 & & & Above CING & 0,74461 & \\
\hline
\end{tabular}

Source: Global Peace Index, calculation authors

The Figure 2 demonstrates graphically the extremely high differences in the allocation of the total world security and military potential across the individual countries. These findings deserve more and deeper analysis, including the study of the situation in EU countries and particularly Slovakia. 


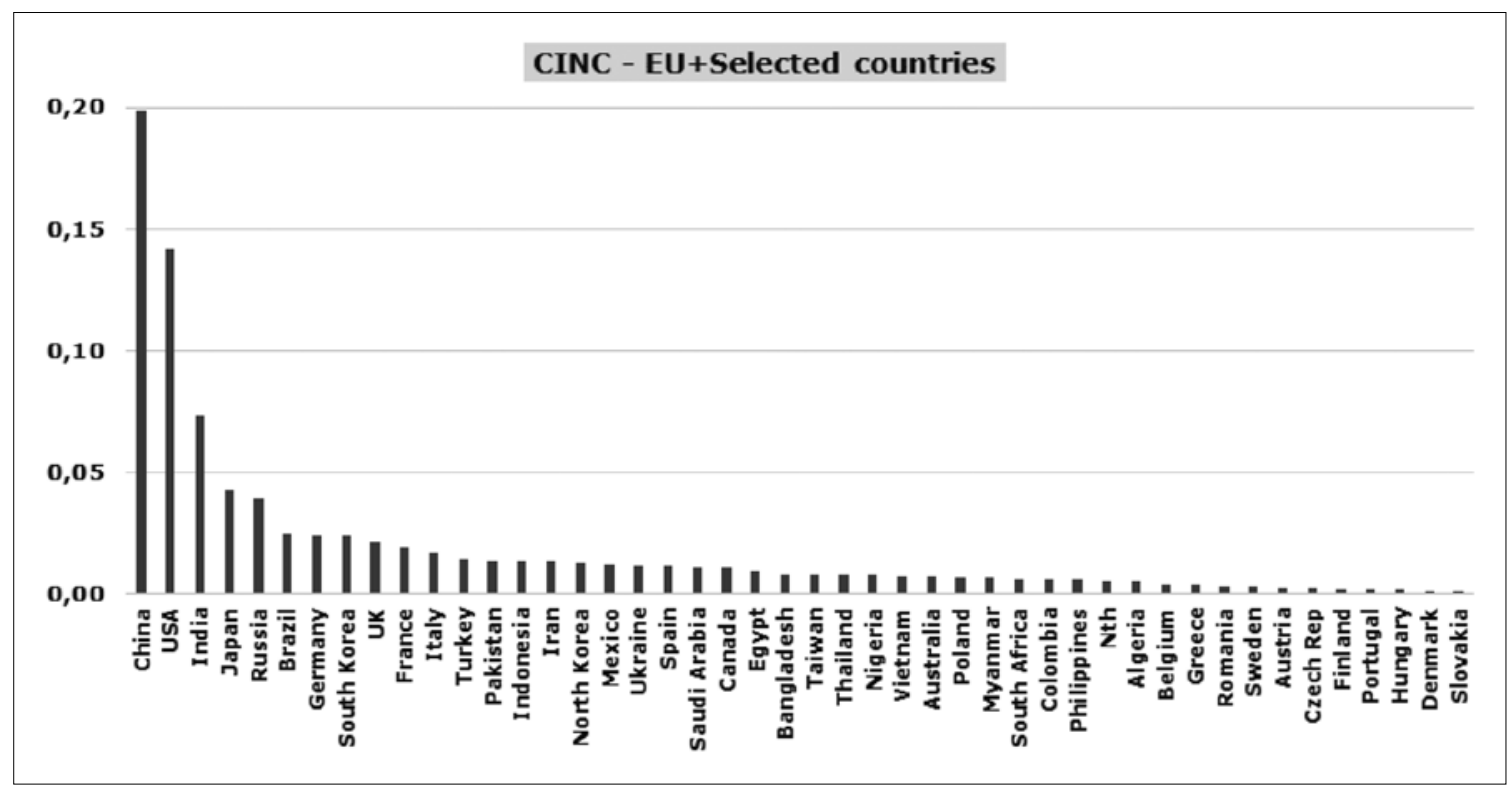

Figure 2. Differences in the allocation of the total world security and military potential across the individual countries

Source: Global Peace Index, calculation authors

Figure 3. presents relation between GDP per capita and Composite Index of National Capabilities. It demonstrates also the pertaining high differences in contribution of these countries into their military budget and strengthening their position, with Germany, UK and France at the top. Even the economically strong EU countries like Netherlands, Belgium, Denmark, Austria and Scandinavian countries are lagging with their budget, significantly behind. All new member countries, including Slovakia, are fighting with their budget balances, which makes for them the postulated budget goals practically not achievable.

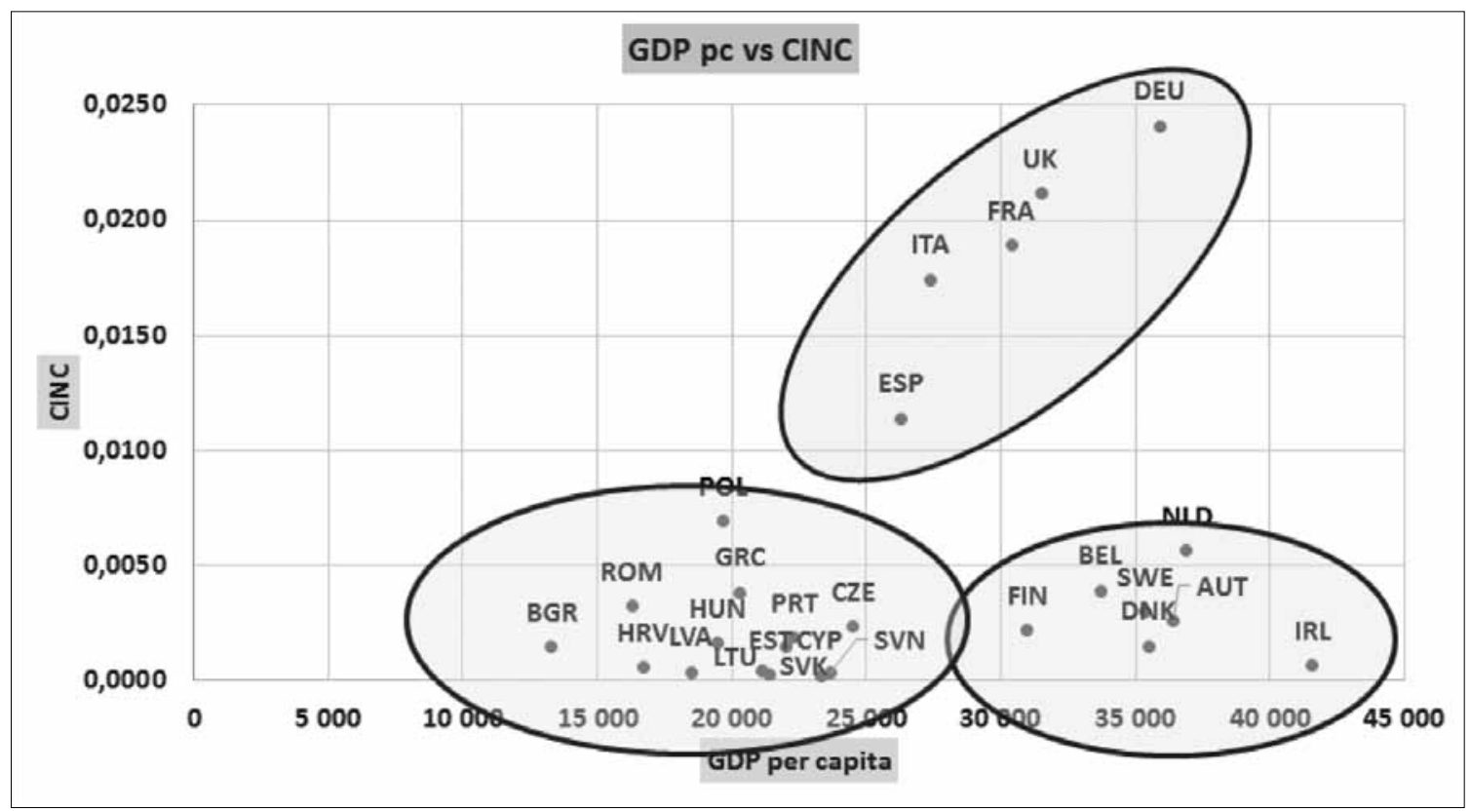

Figure 3. GDP per capita and Composite Index of National Capabilities

Source: Global Peace Index, calculation authors 


\section{Conclusion}

Economic growth in the European Union over the last decade has brought quite satisfactory development. Its impact has been reflected in the daily life of the majority EU citizens. The level of employment brought a relatively satisfactory income situation for households, which contributed significantly to improving the quality of life of millions of Europeans.

Despite this, however, the past several years have brought to the European countries another type of problems and unrest. The quality of life of people in many cities, regions and countries is jeopardized and hampered almost on a daily basis by various conflicts. The safety and security issues in the daily life of people and their families are almost permanently presented as one of the most important social and political topics. The last development on the international scene, namely the tragic terrorist attacks raises the questions on the roots of these antihuman activities. The urgent questions are raised also in connection with the last political development in many countries, where the right-wing parties are gaining relatively high support, or they are significantly tolerated.

Such development requires the mobilization of all democratic forces in order to stop, or at least to decrease such anti-democratic movements. The affective fight against international terrorism however requires not only peaceful political support, but also the readiness of countries to fight against terrorist activities and adoption of stronger measures in safety and security protection of their people and territories. To do this effectively, all countries should take part in such a joint endeavor. This also means, that they should be aware of their technical and military readiness to cope with such missions. The goal of our paper was to mobilize the peoples' awareness on the current situation with the safety and security potential within EU countries. We also wanted to show, how the safety and security potentials are measured and how they could be interpreted under the economic and social frame of individual countries. Our particular attention was devoted to the situation of Slovakia.

\section{References}

Antušák, E.; Kopecký Z.2005. Crisis management and crisis communication. Praha: Vysoká škola ekonomická v Prahe, 2005, s.91, ISBN 80-245-0945-8.

Barberis, S.; Roncallo, F.; Traverso, A. 2017. Towards innovative district energy management: a case study with stochastic renewable generators, Entrepreneurship and Sustainability Issues 4(3): 294-309. http://dx.doi.org/10.9770/jesi.2017.4.3S(5)

Buzan, B. 2005. Security: A new framework for analysis. Brno: Centre of the Strategic Study, p. 267. ISBN 80-90-3333-6-2.

Centre For International Statistics At The Canadian Council On Social Development. 1998. Personal Security Index-PSI. In: CSLS Conference on the State of Living Standards and the Quality of Life in Canada. October 30-31.p. 19.

Corruption Perception Index, Transparency International, 2015. . Available on the Internet https://www.transparency.org/cpi2015/

Drennan, T.; Mcconnell, A. 2007. Risk and Crisis Management in Public Sector. Routledge. Abingdon. 2007. p. 249. ISBN 978-0-41537815-4.

EUROSTAT. 2015. Quality of Life. Facts and views.2015.Luxemburg. Office of European Union. p. 268. ISBN 978-92-79-43616-1.

Gandini, A.; Garmendia, L.; San Mateos, R. 2017. Towards sustainable historic cities: mitigation climate change risks, Entrepreneurship and Sustainability Issues 4(3): 319-327. http://dx.doi.org/10.9770/jesi.2017.4.3S(7)

Gasparènienè, L.; Remeikienè, R.; Sadeckas, A.; Ginevičius, R. 2016. Level and sectors of digital shadow economy: the case of Lithuania, Entrepreneurship and Sustainability Issues 4(2): 183-197. http://dx.doi.org/10.9770/jesi.2016.4.2(6)

Hastings, D., A 2009. The Human Security Index, An Update and a New Release. Available on the Internet www.humansecurityindex.org

Horák, R. a kol. 2015. Principles of society protectioni. Ostrava. Key publishing.s.r.o.2015. p. 474. ISBN 978-80-7418-236-5.

Institute for Economics And Peace. 2015. Global Peace Index 2015. Mexico. p. 127. ISBN 9780-994-2465-3-2. 
Institute for Economics And Peace. 2015. Positive Peace Report 2015. Mexico. p. 84. ISBN 9780-994-2465-5-6.

Institute for Economics And Peace.2015. Peace and Corruption 2015. Mexico. p. 26.

Siller, H., Cibak, L.: Korruption und ihre gesamtwirtschaftliche Bedeutung, in Kriminalistik-Osterreich, 1/2016, ISBN 978-3-78320804-7

Kabat, L., Siller, H..2014. Das Benford Gesetz, in Kriminalistik-Osterreich, 4/2014, ISBN 978-3-7832-0804-7

Koop, G.: Analysis of Economic Data, 2nd ed., John Willey \& Sohns, NJ, ISBN 10:0-470-02468-2

Kováč, M.; Hudáková, M. 2015. Measuring of the security citizens in terms teritorial units of the Slovak Republic. Wolters Kluwer.2015. p. 134 .ISBN978-80-7552-227-6.

Legatum Institute. 2013. The Legatum Prosperity Index 2013.London.2013. p. 76 ISBN 978-1-907409-27-1

Míka,V. 2013. Methods and techniques in the process of the risk management .Žilina. Žilinská univerzita. 2013 .s.230.ISBN 978-805540642-8.

Ministry Of Interior Of The Slovak Republic. 2016. Maps of crime. . Available on the Internet http://www.minv.sk/?mapy_TC_v_ SR 2015 .

Novák, L. a kol. 2010. Resource planning for crisis solution. .Bratislava. crr.sk.s.r.o. 2010. p. 307. ISBN 978-80-970272-4-7.

Oates, M.; Melia, A.; Ferrando, V. 2017. Energy balancing accross cities: Virtual Power Plant prototype and iURBAN case studies, Entrepreneurship and Sustainability Issues 4(3): 351-363. http://dx.doi.org/10.9770/jesi.2017.4.3S(10)

Rektořík, J.a kol. 2004. Crisisi management in public administration. Praha. Ekopress, s.r.o. 2004, s.249. ISBN 80-86119-83-1.

Resdal. M. 2013.Public Security Index Central America: Costa Rica, El Salvador, Guatemala, Honduras, Nicaragua and Panama. 1st.ed. Ciudad Autónoma de Buenos Aires, RESDAL, 2013.p.152.ISBN 978-987-28638-6-9.

Research Institute Credit Suisse. 2015. Global Wealth Data Book 2015. Zurich.s.158. Available on the Internet www.credit-Suisse.com/ researchinstitute.

Rezk, M. A.; Ibrahim, H. H.; Tvaronavičienè, M.; Sakr, M. M.; Piccinetti, L. 2015. Measuring innovations in Egypt: case of industry, Entrepreneurship and Sustainability Issues 3(1): 47-55. http://dx.doi.org/10.9770/jesi.2015.3.1(4)

Sarkees, M., R., Wayman, F. 2010: The Correlates of War Project: COW War Data, 1816 - 2007. Available on the Internet, http://cow. dss.ucdavis.edu/data-sets/COW-war

Sarkees, M., R., Wayman, F. The Correlates of War Project: COW War Data, 1816 - 2007. 2010. Available on the Internet http://www. correlatesofwar.org/

Šimák, L. 2016. Crisisi management in public administration. Žilina: FŠI ŽU. 2016. p. 263. ISBN 978-80-554-1165-1.

Štitilis, D.; Pakutinskas, P.; Malinauskaitè, I. 2016. Preconditions of sustainable ecosystem: cyber security policy and strategies, Entrepreneurship and Sustainability Issues 4(2): 174-182. http://dx.doi.org/10.9770/jesi.2016.4.2(5)

Supreme Audit Office of the Slovak Republic. 2015. Summary Report on the outcome of efficiency and effectiveness in exercising the powers of the Slovak villages. .29.6.2015. Available on the Internet: https://www.nku.gov.sk/spravy-o-vysledkoch-kontrol-od-roku-2012

Teivāns-Treinovskis, J.; Amosova, J. 2016. Some aspects of criminal environment impact on sustainable entrepreneurship activities, Entrepreneurship and Sustainability Issues 4(1): 17-27. http://dx.doi.org/10.9770/jesi.2016.4.1(2)

The Stiglitz Report: Reforming the International Monetary and Financial Systems in the Wake of the Global Crisis, 2010. . Available on the Internet https://www.amazon.com/Stiglitz-Report-Reforming-International-Financial/dp/1595585206

Travkina, I. 2015. Export and GDP Growth in Lithuania: Short-run or Middle-run Causality?, Entrepreneurship and Sustainability Issues 3(1): 74-84. http://dx.doi.org/10.9770/jesi.2015.2.4(7)

Tvaronavičienė, M. 2016. Entrepreneurship and energy consumption patterns: case of hoseholds in selected countries, Entrepreneurship and Sustainability Issues 4(1): 74-82. http://dx.doi.org/10.9770/jesi.2016.4.1(7)

User Guide for the Global Food Security Index. Available on the Internet ,http://foodsecurityindex.eiu.com/, 2015 
Vighová,A;Štangová,N.2017.Financial audit as a tool for management control.Account and Financial Management Journal. Evereant. Volume 2 Issues 2 Feb.2017: 617-622. ISSN:2456 - 3374

Wiberg, H.: Security problems of small nations. In. Brassey's Atlantic Commentaries No. 8. Small States and the security challenge in the new Europe. London: Bracey’s, 1996. p.22-35. ISBN 85-753-153-1

Ladislav KABÁT. Professor, his field is social statistics and quantitative analysis with special interest in data collection, data processing and data quality. In past, he held positions - Director of Statistical Division of the FAO UN in Rome, Member of the Statistical Advisory Committee of the EU. Participated in various projects oriented on building and strenthening the statistical systems in developing countries.

Stanislav FILIP, Assoc prof. Ing. PhD. is the Vice-Rector for foreign affairs an teacher of the School of Economics and management in Public Administration in Bratislava. His text books, monographs and scientific papers deal with the Risk and crisis managemtn in public sector, international crisis management and public administration at the national and EU level. He is succesfull leader and manager of the several scientific projects with support from the EU structural funds. He also organise and control international colaboration and Erasmus plus program with the high educational and research institutions in abroad.

Lubica FILIPOVÁ, Mgr. doctoral student of the Fakulta Faculty of Economics and Business, Pan-European University in Bratislava. Her scientific papers deal with macro economics issues, and with the security importance on turism development. 